\title{
Journal of Textile and Clothing Science
}

Available online at http://www.jtcsonline.com

\section{BOOK PROMOTION}

\section{TEXTILE DYES}

\section{N. N. Mahapatra}

President, Business Development, Colorant Ltd, Ahmadabad.

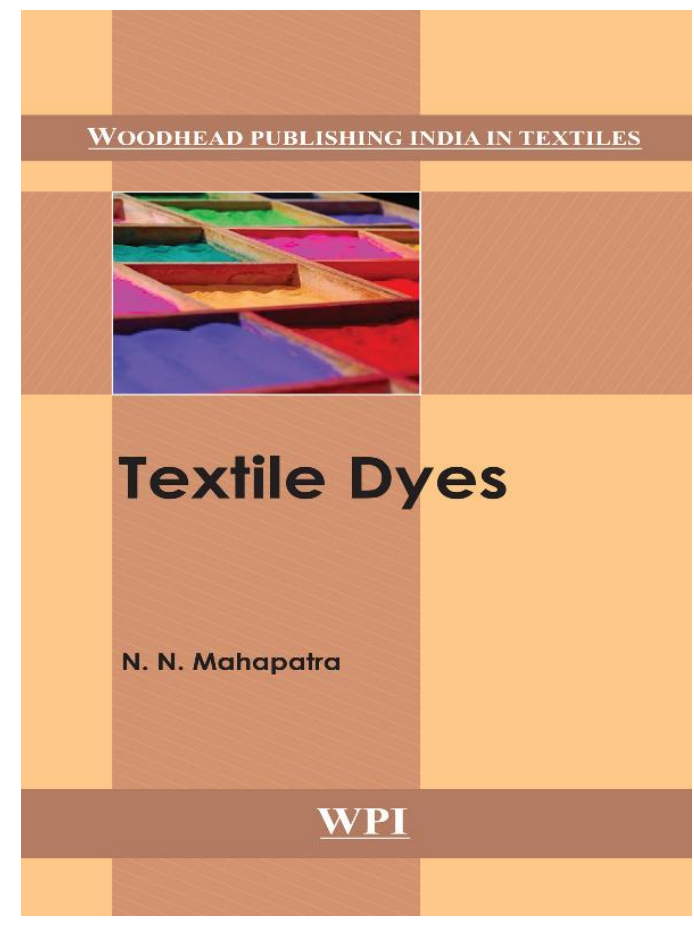

\section{A B OUT THE BOOK}

Textile Dyes has its each chapter simplified into the most important training of dyes. The author has dealt with the records, manufacturing, homes, identity, stripping, trying out and alertness of dyes. The book is written in a very easy language and in a lucid way. The e-book can be useful to the fabric students, studies students, supervisors working in the dyes and textile industries. When you consider that last years, the charges of $\mathrm{H}$ Acid changed into so excessive that the fees of Reactive Dyes went skyrocketing. All and sundry inside the enterprise turned into concerned for $\mathrm{H}$ Acid. At that time, all people got here to realize about $\mathrm{H}$ Acid and the way essential it become for the dyes enterprise as uncooked material or dye intermediate. However, they did now not understand the function of $\mathrm{H}$ Acid in manufacturing of reactive dyes. This book deals about the producing method.

\section{Preface}

Amid our school days, we used to peruse a book on "Science of Dyes," composed by Prof Dr. Venkatraman. That was into numerous volumes and enormous in measure. It was a Bible for understudies contemplating Dyestuff Chemistry. In any case, the understudies thought that it was extremely hard to get it. At that point, Dr. Shenai composed minimal disentangled books on colors and application. We read those books in our school time.

By the by, every one of these books turned out to be exceptionally scholastic. When we entered the textile business, the situation was distinctive. The practices embraced in colors units and textile organizations were altogether different.

Until the point that then no one from the business composed any book on colors and textiles. In this way, I have put my 30-year shop floor encounter into the book, which I have titled "Textile Dyes."

Every part is improved into the real class of colors. I have managed the history, fabricating, properties, distinguishing proof, stripping, testing and utilization of colors.

It is composed in an extremely basic dialect and in a clear way.

The book will be useful to textile understudies, look into understudies, directors working in the colors and textile enterprises.

Throughout the previous 2 years, the costs of $\mathrm{H}$ Acid were high to the point that the costs of Reactive Dyes went soaring. Each individual in 
the business was stressed for $\mathrm{H}$ Acid. I found that time everyone came to think about $\mathrm{H}$ Acid. How pivotal crude material or color middle of the road it was for the colors business. In any case, they did not know the part of $\mathrm{H}$ Acid in assembling of receptive colors. This book bargains about the assembling procedure.

This will be useful to both the colors business and textile industry.

\section{Book Details}

$\begin{array}{lll}\text { ISBN } & : & 9789385059049 \\ \text { Pages } & : & 230 \\ \text { Pub Date } & : & \text { Jan. } 2016 \\ \text { Price } & : & \text { Rs. } 2995 \\ \text { Binding } & : & \text { Hardback }\end{array}$

\section{Table of contents}

Chapter 1: Introduction to textile dyes Chapter 2: Direct dyes

Chapter 3: Azoic dyes (Naphthol dyes)

Chapter 4: Sulphur dyes

Chapter 5: Vat dyes

Chapter 6: Chrome dyes (Mordant dyes)

Chapter 7: Metal-complex dyes

Chapter 8: Acid dyes
Chapter 9: Basic dyes

Chapter 10: Indigo dyes

Chapter 11: Pigment dyes

Chapter 12: Disperse dyes

Chapter 13: Reactive dyes

\section{How to Order?}

Place your order by sending email at: marketing@sarabooksindia.com info@woodheadpublishingindia.com You can also confirm your orders on phone to Woodhead Publishing India

Landline no.: 011-23266107, 011-43612145

\section{Preview This Book}

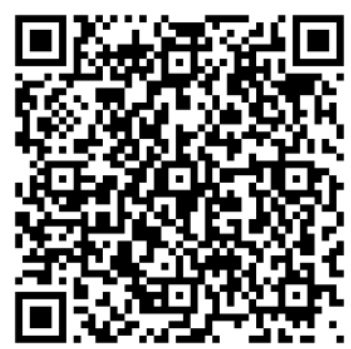

Scan above $\mathrm{QR}$ code to preview this book on your cell phone

(C2018 by the authors.This work is licensed under a Creative Commons Attribution-NonCommercial-

NoDerivatives 4.0 International License. 